\title{
11 Industry 4.0 and reshoring
}

\author{
Steffen Kinkel
}

\subsection{Introduction}

The rise of global value chains (GVCs) has transformed the global manufacturing landscape dramatically in recent decades (Timmer et al., 2016; Brennan et al., 2015). Globally fragmented production processes often result in products consisting of components from a variety of countries, which can be best described as 'made in the world' (WTO, 2011).

However, highly fragmented supply chains come at a price. Disadvantages include higher coordination efforts, a longer time-to-market, quality issues, a loss of flexibility and a loss of the ability to react quickly to changes in market demand (e.g. Fratocchi et al., 2014, 2016; PricewaterhouseCoopers, 2014; Kinkel, 2012; BCG, 2011; Kinkel and Maloca, 2009). Moreover, the rise of GVCs and the offshoring of production activities have been blamed for job losses in manufacturing sectors of the US and European countries.

As a result, the so-called reshoring or backshoring of once-offshored manufacturing capacities back to the home country has recently received broad attention in the academic literature (e.g. De Backer et al., 2016; Di Mauro et al., 2018; Kinkel, 2014; Stentoft et al., 2016; Wiesmann et al., 2017), and even more by policy makers and in public debates. The debate on re-industrialization (Pisano and Shih, 2009, 2012) in the US and Europe is to some extent based on expectations that reshoring activities of manufacturing companies might help to restore industrial competitiveness in high-wage countries. It is fuelled by the assumption that cost advantages of important low-wage countries, in particular China, may be gradually eroded by higher wage increases in the next five to ten years (BCG, 2011).

This chapter investigates the relationship between investments in new digital production technologies, which are currently discussed under headings such as 'Industry 4.0' (I4.0) or 'Industrial Internet of Things (IIoT)', and reshoring or backshoring decisions of manufacturing companies.

It is assumed that the use of I4.0 technologies may affect GVCs in two ways: first, because increased productivity provided by I4.0 production technologies may neutralize the factor cost advantages of offshoring locations and make labour arbitrage less appealing; and, second, because increased flexibility 
provided by I4.0 technologies may provide an incentive for firms to locate production close to their European customers and regain some of the responsiveness lost by having finely sliced their global supply chains.

The empirical test is based on a large dataset of almost 1,300 German manufacturing companies from the European Manufacturing Survey (EMS). This dataset has the advantage of including variables on both reshoring and investments in modern production technologies, and a number of additional control variables.

\subsection{Definitions and some theory on reshoring and I4.0}

\subsubsection{Reshoring/backshoring}

Reshoring or backshoring is the decision to relocate manufacturing activities back to the home country of the parent company (Kinkel and Maloca, 2009; Arlbjørn and Mikkelsen, 2014; Fratocchi et al., 2014; Foerstl et al., 2016). Reshoring or backshoring can origin from and be relocated to wholly owned production sites of the company (captive mode) as well as from foreign suppliers or to home-based suppliers (outsourced mode), thus covering different ownership modes of manufacturing in the host and home countries. In this context, Gray et al. (2013) distinguish four different reshoring options (see Figure 11.1): (a) in-house reshoring, when a company is relocating manufacturing activities being performed in wholly owned offshore facilities back to wholly owned facilities in the home country; (b) reshoring for outsourcing, when a company is relocating manufacturing activities being performed in wholly owned offshore facilities back to home-based suppliers; (c) reshoring for insourcing, when a company is relocating manufacturing activities being performed by offshore suppliers back to wholly owned facilities in the home country; and (d) outsourced reshoring, when a company is relocating

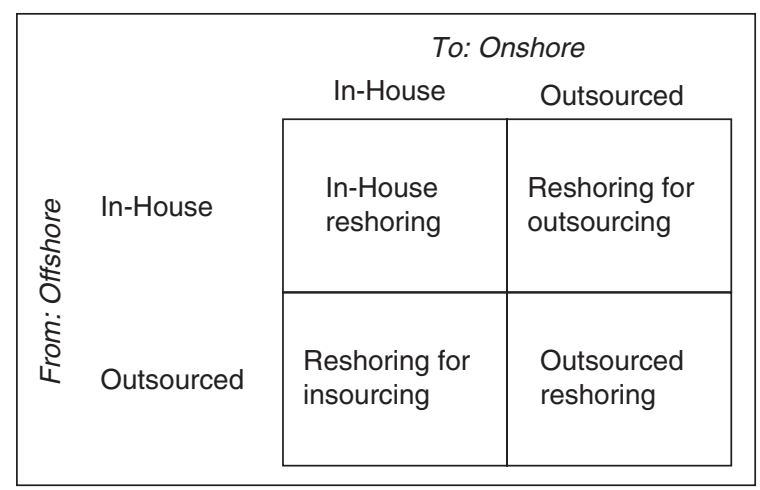

Figure 11.1 Reshoring options.

Source: Gray et al. (2013). 
manufacturing activities being performed by offshore suppliers back to homebased suppliers. The authors characterize all these different options basically as location decisions.

There is no explicit theory of reshoring or backshoring. The literature explains reshoring in the framework of existing theories of the multi-national firm, as a reverse or subsequent decision of a previous offshoring decision (Bals, et al., 2013; Ellram et al., 2013; Gray et al., 2013; Tate, 2014; Foerstl et al., 2016). To put it simply, reshoring takes place when the trade-offs between cost advantages, market and knowledge seeking, transaction costs and maintaining control are no longer advantageous for the firm.

Through the lens of internalization theory (Buckley and Casson, 1976; Casson, 2013; Rugman, 2010) and Dunning's 'eclectic paradigm' (Dunning, 1980, 1988), reshoring is the result of changes in the ownership, location and/or internalization advantages from international production, or a consequence of a wrong assessment of these advantages (Ellram et al., 2013; Fratocchi et al., 2016). The international expansion of multi-national firms was fuelled by labour arbitrage, a substantial lowering of import barriers for intermediate goods, lower cost of cargo transport and the rapid development of ICTs which supported trans-border communication and coordination (Dicken, 2014). Factors that contributed to a wrong assessment of location, internalization or ownership advantages include rising labour costs in foreign locations and narrowing wage differentials, transport costs and long lead-times in transport, currency fluctuations, the cost for obsolete materials ordered according to a long-term and incorrect forecast, unforeseen coordination costs such as additional travelling expenses, or a loss of intellectual property to foreign competitors or suppliers (Handfield, 1994; Kinkel and Maloca, 2009; Holweg at al., 2011; Nassimbeni, 2006). Case studies have shown that some managers have offshored manufacturing activities based on simple comparisons of easily measurable costs, in particular labour costs (Kinkel and Maloca, 2009).

The resource-based view (RBV) of the firm (Wernerfelt, 1984; Prahalad and Hamel, 1990) can also be applied to explain reshoring strategies. Firms can develop organizational processes and routines that cannot be acquired over markets, enabling them to use resources and develop capabilities more efficiently and effectively (Barney, 1991; Teece et al., 1997, 2002). Reshoring decisions may thus result from the limited abilities of companies to sufficiently develop and maintain such critical capabilities in foreign locations, or to exploit the host country's resources in order to create competitive advantage for the multi-national company as a whole (Canham and Hamilton, 2013). Here, advanced production technologies also come into play. Some organizations are able to adopt manufacturing processes to develop unique and barely imitable competences at specific locations and to exploit these resources in a specific and more effective way (Broedner et al., 2009; Grant, 1991).

Transaction cost theory (TCT) can also help us understand reshoring. High and growing transaction and coordination costs can be strong arguments for 
reconcentrating manufacturing activities via reshoring. TCT points to various reasons for a wrong assessment of the 'hidden' costs of offshoring. Bounded rationality and possible contingencies in transactions across companies and countries may lead to inaccuracy of the projected cost and performance of manufacturing offshoring decisions (Pisano, 1990; Pisano and Shih, 2009; Lewin et al., 2009; Cabral et al., 2013), higher than expected costs, poorer than expected quality and higher than expected efforts for the management of trans-border activities (Fredriksson and Jonsson, 2009; Tate et al., 2009). Biases in decision making such as the 'bandwagon effect' (Abrahamson and Rosenkopf, 1993), aiming at imitating competitor behaviour and 'following the herd', can also be explained by bounded rationality (Barthélemy, 2001).

The level of uncertainty is also influencing companies' offshoring and reshoring decisions. Foerstl et al. (2016) differentiate between environmental uncertainty, supply chain complexity and task uncertainty as possible drivers for reshoring decisions. Environmental uncertainty encompasses the perceived degree of volatility and unpredictability of a foreign market, including unforeseen cost increases, quality and flexibility issues, raw material shortages and currency fluctuations (Ellram et al., 2013; Gray et al., 2013; Tate, 2014). Supply chain complexity includes vertical complexity, horizontal complexity, geographical dispersion and the length of the supply chain (Choi and Hong, 2002). It can lead to excessive coordination and monitoring efforts, rising transportation cost or high amounts of working capital in safety stock (Lewin et al., 2009; Tate et al., 2011; Ritter and Sternfels, 2004). Task uncertainty is another factor influencing offshoring and reshoring decisions. Here, to some extent, the uncertain potential of technological innovations in manufacturing processes, e.g. by an intensified use of I4.0, come also into play. A greater adoption of I4.0 might enable more flexible, autonomous and less labour-intensive production modes, giving advantages to reshoring decisions over low-wage manufacturing activities (Handley and Benton Jr., 2013; Lasi et al., 2014). Asset specificity is also closely linked to the implementation of new product or production technologies, e.g. I4.0 technologies. It involves specific durable investments such as technology or knowledge and skills that are required to realize efficient processes and transactions. A high degree of asset specificity appears to be most critical for the integration of manufacturing activities and their control under unified governance (Williamson, 1985), in particular in cases of high product or process complexity (McIvor, 2009). The higher and more specific investments in advanced production technology are, the higher the possibility to integrate the specific manufacturing operations at one focal plant, favouring reshoring rather than additional offshoring activities.

\subsubsection{Industry 4.0}

Many observers today agree that we are witnessing a technological revolution in manufacturing (Brynjolfsson and McAfee, 2014; Ford, 2015; OECD, 2016, 2017). This revolution is based on a variety of digital production 
technologies (e.g. sensors and actors, networked production, advanced robotics and $3 \mathrm{D}$ printing), new materials and IT-enabled management processes (e.g. enterprise resource planning and production control, data analytics and artificial intelligence). In the manufacturing context, this group of technologies is often labelled as the Fourth Industrial Revolution - after mechanization, electrification and automation (Figure 11.2) - or I4.0 (Kagermann et al., 2013; Spath et al., 2013; Bauernhansl, 2014). The German term 'Industry 4.0' is widely used in the European context and sums up a group of production technologies where components and machines communicate and coordinate their operations in factories and (global) value chains (Brennan et al., 2015; Bauernhansl, 2014; Kagermann et al., 2013; Spath et al., 2013; OECD, 2017; UNCTAD, 2017). Observers expect that I4.0 will allow a highly flexible and at the same time highly efficient production which makes it possible to produce individualized products under the economic conditions of a mass producer (Lichtblau et al., 2015).

A main component of I4.0 are cyber-physical systems (CPSs), which comprise 'smart machines, warehousing systems and production facilities that have been developed digitally and feature end-to-end ICT-based integration, from inbound logistics to production, marketing, outbound logistics and service' (Kagermann et al., 2013, p. 14). This is done by embedding technology that can take on tasks like sensing or automation into physical objects and connecting them via the Internet. In other words, CPSs integrate all stages of the physical production process over the Internet in order to create a seamless exchange of information between these two worlds.

\subsubsection{Research question}

This chapter tests the assumption that firms' adoption of I4.0 technologies via productivity and flexibility effects - affects location decisions of manufacturing activities. If I4.0 really leads to higher productivity, a higher degree of customization and more flexibility to manufacturing firms, this may offset the labour cost advantages firms enjoy in offshoring locations. As a consequence, Western Europe may become again a more attractive location for manufacturing because firms benefit from geographical proximity to their customers 'in the market and for the market' (Brennan et al., 2015) - without suffering from higher production costs. Proximity to the customer is increasingly competing with the long-dominant GVCs, incorporating a variety of operations from different low-wage countries, resulting in high complexity and increasing flexibility disadvantages, especially in the case of short-term and individual customer requests (Kinkel et al., 2016).

Against this background, the research question is posed as follows:

Is there a positive relationship between the propensity for reshoring/backshoring and the use of I4.0 technologies in manufacturing companies, once we correct for other firm characteristics? 


\section{Industrial revolutions and "Industry 4.0"}

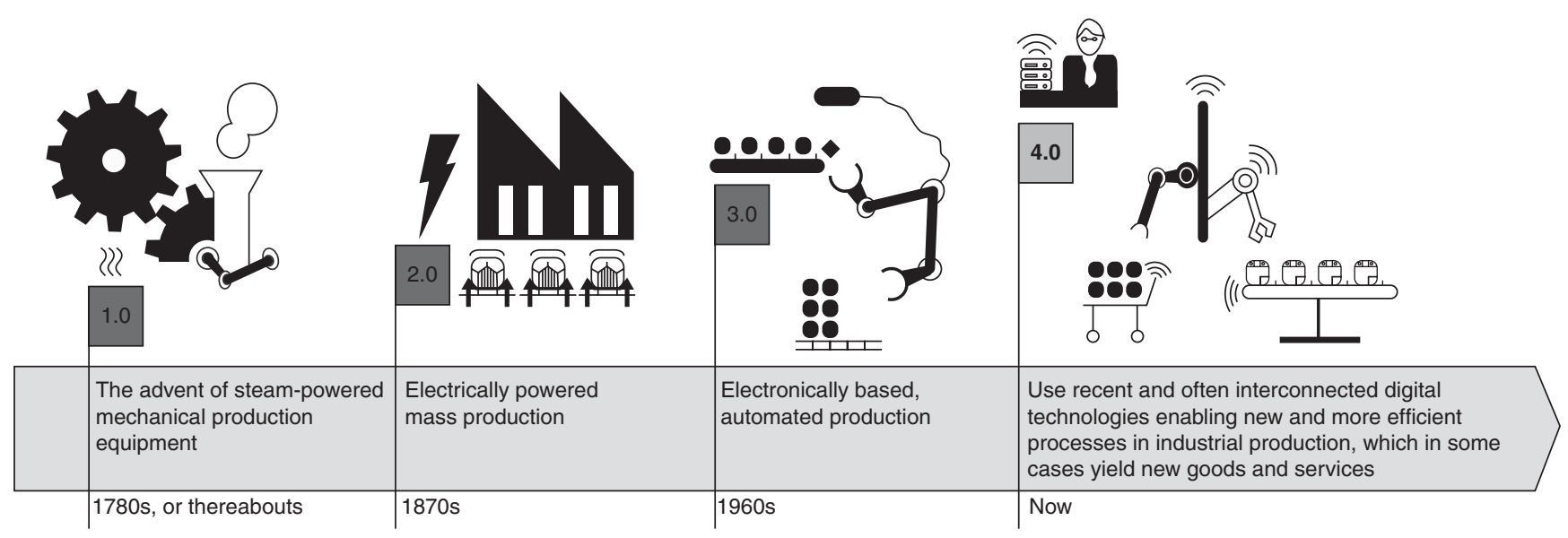

Figure 11.2 Industrial revolutions of the past and I4.0.

Source: OECD (2017). 


\subsection{Data}

The relationship between reshoring/backshoring activities and the use of I4.0 technologies is tested with German data from the 2015 edition of the EMS. The EMS is a firm-level survey that investigates product, process, service and organizational innovation in European manufacturing. It is organized by a consortium coordinated by the Fraunhofer Institute for Systems and Innovation Research (ISI).

The EMS includes detailed information on the degree of utilization of a number of production technologies, on innovation input such as research and development $(R \& D)$ expenditure, innovation output such as the introduction of new products to the market, the qualification structure of the employees, and a number of control variables such as firm size, exports, the position of the firm in the value chain and the characteristics of the main product and of the production process. This makes it possible to study the effects of reshoring/ backshoring and investment in production technologies in detail.

The German subset of the EMS 2015 comprises data from a total of 1,282 randomly selected companies (Kinkel and Maloca, 2009). It provides a representative picture of the manufacturing sector in Germany in terms of size classes, sector structure and regional distribution. The survey addressed all manufacturing sectors in Germany (NACE Rev. 2 classes 10-33 with at least 20 employees). In order to ensure the representativeness of the results and comparability with earlier analyses, the descriptive data on offshoring and backshoring behaviour were weighted in terms of size classes, sectors and regional structure analogously to the population of all manufacturing enterprises with 20 or more employees.

The EMS measures reshoring/backshoring asking firms whether they had relocated production activities from their own affiliates or from suppliers back to the home country during the past two years. As a consequence, backshoring is not just divestment of assets abroad; it also includes activities which have been contracted out to third parties. In other words, backshoring firms do not necessarily possess affiliates and production activities abroad.

I4.0 technologies are counted with an array of questions on the use of eight different digitization technologies that can be understood as enabling technologies for digital networked production according to the I4.0 model.

\subsection{Descriptive results on reshoring}

As the descriptive results of the survey round of 2015 show, the backshoring of production capacities has risen slightly compared to the 2012 survey results. From 2013 to mid-2015, about 3\% of German manufacturing companies have shored parts of their foreign production capacities back to Germany (Kinkel and Jäger, 2017). This does not necessarily mean that a foreign site had to be closed, as partial capacities may also have been transferred back. At the same time, production offshoring activities abroad continued to stay at a low level. 


\section{Steffen Kinkel}

Only $9 \%$ of German manufacturing companies offshored parts of their production abroad from 2013 to mid-2015. This value is only barely higher than the $8 \%$ at the last survey in 2012, which represented the lowest level measured since the start of the survey in the mid-1990s (Figure 11.3). Thereby the declining trend of the past 12 years has not yet reversed. Fewer and fewer German companies reduce domestic production capacities in favour of foreign locations.

Hence, there is currently one backshoring company for every three offshoring companies. A share of about 3 per cent of firms choosing to backshore suggests that backshoring is not a big trend. However, it is a relevant phenomenon. When extrapolated to the entire German manufacturing sector, absolute numbers account actually for around 500-550 German companies performing backshoring activities per year. Further time-series analysis of panel data shows that every fourth to sixth offshoring activity is countered by a backshoring activity within two to five years (Kinkel, 2014). Approximately 20\% of German companies' backshoring decisions can be characterized as mid- to long-term reactions to changing local environments, whereas $80 \%$ can still be characterized as short- to mid-term corrections of prior location misjudgements (Kinkel, 2014; Kinkel and Maloca, 2009).

The main source countries of German companies' backshoring activities were the Western European EU 15 countries (32\%), followed by other (than China) Asian countries (23\%), North America (16\%), China (13\%), and the Middle and Eastern European EU 13 countries (10\%). In the previous surveys of 2012, 2009 and 2006, the EU 13/12/10 have been much more important for German companies' backshoring activities, accounting for around $50 \%$ of the backshoring cases in each round.

The most important reasons for the backshoring activities of German manufacturing companies are the lack of flexibility (56\%) at the offshored location or in the resulting supply chain and a low quality (52\%) of the goods produced. Both reasons are relevant for more than half of all backshoring decisions and remained virtually unchanged since the last survey. The reduced flexibility and delivery capability may be due to problems and distances in their own supply chain between the sites, as well as limited access to local supplier networks abroad. Quality issues stem from underestimated efforts to ensure the desired product and process quality in countries with a different mentality and culture, as well as internal quality assurance efforts. On the other hand, innovation-relevant factors such as the risk of loss of know-how at the foreign location (6\%), the proximity to domestic R\&D (5\%) or the availability or fluctuation of skilled workers at the foreign site $(0 \%)$ play a minor or no role for the reshoring decisions of German manufacturing companies.

\subsection{Descriptive results on the use of digitization technologies/Industry 4.0-enabling technologies}

The EMS includes questions on the use of eight different digitization technologies that can be understood as enabling technologies for I4.0. These were assigned to the following three technology fields: 


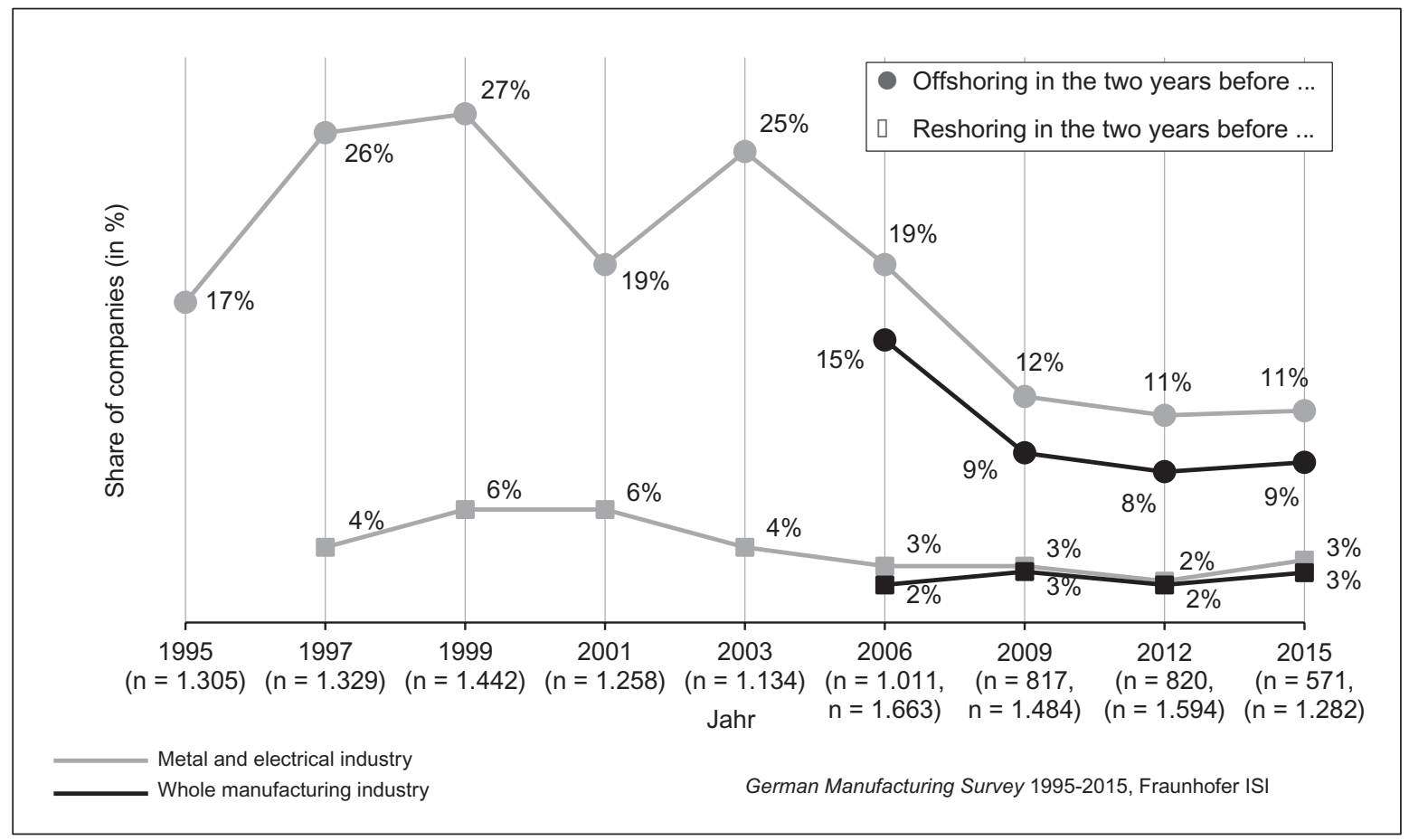

Figure 11.3 German manufacturing companies' offshoring and backshoring activities over time. 
- Digital management systems comprise two basic technologies for the management of IT-related processes of production and product development:

- $\quad$ software systems for production planning and control (enterprise resource planning (ERP));

- $\quad$ product lifecycle management (PLM) systems.

- Wireless human-machine communication encompasses two workplacesupporting IT implementations:

- digital visualization in the workplace;

- mobile/wireless devices for the programming and operation of systems.

- $\quad$ CPSs encompass production-integrated enabler technologies for I4.0:

- $\quad$ digital exchange of disposition data with suppliers or customers (supply chain management (SCM));

- techniques for automation and control of internal logistics;

- a real-time manufacturing execution system (MES).

The share of German manufacturing companies already using these digitization technologies in their manufacturing processes is displayed in Figure 11.4.

As expected, enterprise resource planning (ERP) systems are the most widespread; two out of three manufacturing companies are using this technology. They are already an established standard in production systems. PLM systems, the second technology from the field of digital management systems, are used by only $11 \%$ of the companies and thus much less frequently. The systematic and customer-specific retention and management of product data therefore still seems to place high demands on the management and production processes of companies. Diffusion is quite low, with $6 \%$ of the companies planning to introduce such systems in the next three years. In the case of production and planning systems, this is due to the already high level of penetration; in the case of PLM, however, this is rather sobering and raises questions about the usage barriers.

One-third of the companies use technologies for the digital visualization of the most important information at the workplace in their own production processes. The second technology from the field of wireless human-machine communication, mobile devices for programming and operating systems and machines, is being used by almost one-fifth of the companies. Both technologies in this field also show a comparatively high dynamic of $8-10 \%$ of the companies planning to introduce these technologies in the next three years.

A good quarter to almost a third of the surveyed manufacturing companies use the three digitization technologies in the field of CPS-related operations, Digital Data Exchange with customers and/or suppliers to enable SCM, technologies for the Automated Logistics and Real-time Production Control System. This means that the technologies in this field are used on a comparably broad basis. However, the dynamics of the launches planned for the next three years vary. In the case of Digital Data Exchange with customers and/or suppliers, only a further $5 \%$ of companies plan to introduce this technology, which indicates a certain degree of maturity of this technology to support 


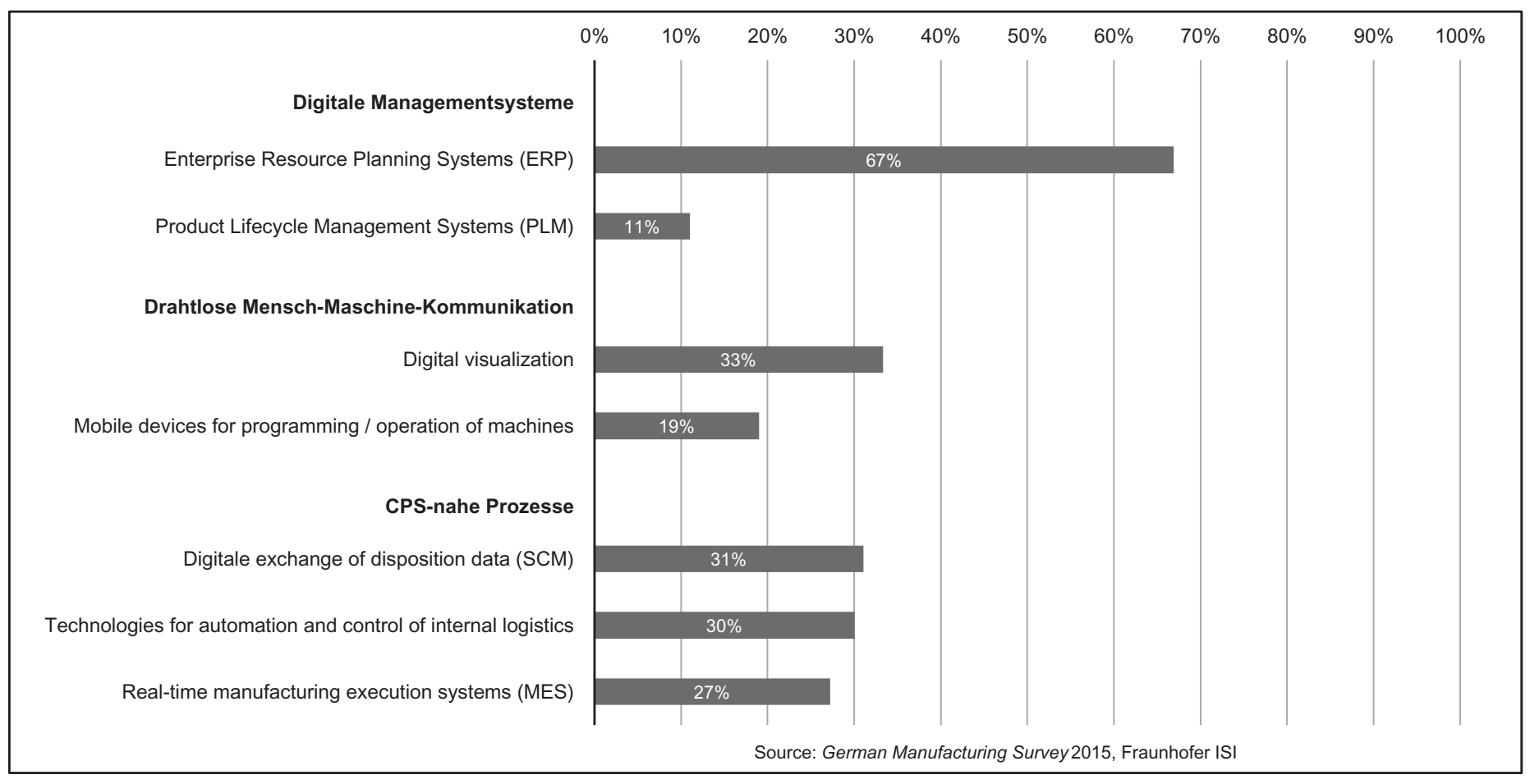

Figure 11.4 Use of I4.0-enabling technologies in the German manufacturing industry Source: Kinkel and Jäger (2017). 
SCM. With the Automated Logistics and the Real-time Production Control System, the dynamics are much higher, with $10 \%$ of the companies planning to introduce these technologies in the next three years.

\subsection{The relationship between the backshoring of production activities and the use of digitization technologies in manufacturing}

A recent study by Kinkel and Jäger (2017) investigates the relationship between reshoring/backshoring of production activities and the use of digitization technologies in manufacturing (I4.0). In order to measure this relationship, the information on the usage of single I4.0-enabling technologies was used to create an I4.0 readiness index. This index can take four values:

Level 0 (non-user) if the company has not yet introduced any technology from the three technology fields.

Level 1 (beginner) if the company has introduced at least one technology from one of the three different technology fields.

Level 2 (active user) if the company has introduced technologies from at least two of the three different technology fields.

Level 3 (advanced user) if the company has introduced at least one technology from all three different technology fields.

If this I4.0 readiness index is applied to the data of the 2015 survey, the following picture emerges (Figure 11.5): 23\% of German manufacturing enterprises do not yet use any of the selected digitization technologies and are therefore still at the very beginning of the path towards I4.0 (level $0-$ non-users); $20 \%$ of the enterprises use at least one technology in one of the technology fields (level 1 - beginners); $30 \%$ use at least one technology in two of the technology fields (level 2 - active users); and 27\% of the enterprises

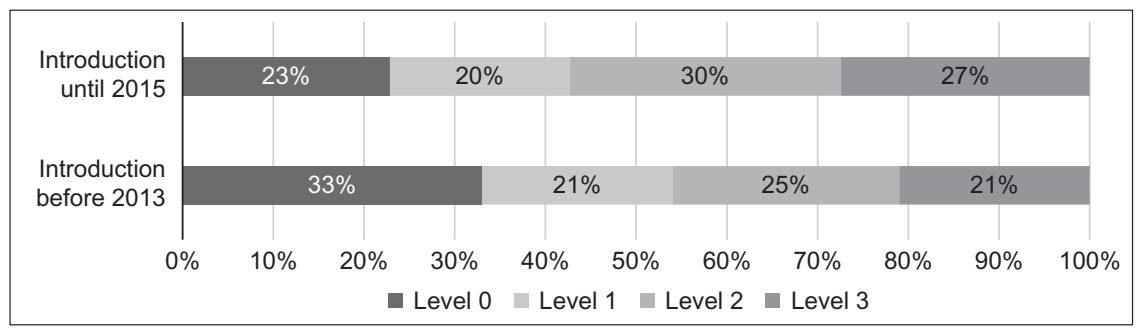

Figure 11.5 Distribution of I4.0 readiness index values.

Source: Kinkel and Jäger (2017), translated from German language. 
use at least one technology from each of the three technology fields (level 3 - advanced users). The 'advanced' companies are already positioned in such a way that they have already gained experience with today's enabling technologies in all three of the technology fields relevant for I4.0. However, this group is remarkably small, with just over a quarter of German industrial companies in this category.

As the reshoring activities are surveyed for the years from 2013 to 2014 and the impact of previous technology usage was to be examined, only the introduction of digitization technologies before 2013 is considered in the following regression model (Figure 11.5). The descriptive analysis shows that 33\% of the German manufacturing companies did not use any of the selected digitization technologies before 2013 (level 0). The group which introduced at least one technology in one of the technology fields before 2013 (level 1) includes 21\% of the companies. About $25 \%$ of the companies belong to level 2 and a relatively small group of $21 \%$ to level 3 .

Based on this $\mathrm{I} 4.0$ readiness index before 2013, we ran a logistic regression model to explain the likelihood of a German manufacturing company to have been active in backshoring manufacturing operations during 2013-2014. The model is significant and shows satisfactory model quality (Table 11.1).

Table 11.1 Logit model for the backshoring propensity of German manufacturing companies

\begin{tabular}{|c|c|c|c|}
\hline $\begin{array}{l}\text { Cox \& Snell: } \\
0.055\end{array}$ & Nagelkerkes: 0.230 & $\begin{array}{l}\text { Regression } \\
\text { coefficient B }\end{array}$ & Sig. \\
\hline Step 1 & $\begin{array}{l}\text { Ln\#employees } \\
\text { sec24_metal \& metal components } \\
\text { sec26_Data processing equipment, electronic } \\
\text { and optical products } \\
\text { sec27_electrical equipment } \\
\text { sec28_machinery \&equipment } \\
\text { medium batch size } \\
\text { large batch size } \\
\text { medium complex products } \\
\text { complex products } \\
\text { supplier company } \\
\text { maincompetition factor: price/cost } \\
\text { Lnimport quota of inputs- } \\
\text { Lnexport quota of inputs1 } \\
\text { Ln share ofunskilled workers } \\
\text { I40-enabling-use-til-2013_level11 } \\
\text { I40-enabling-use-til-2013_level21 } \\
\text { I40-enabling-use-til-2013_level32 } \\
\text { Constant }\end{array}$ & $\begin{array}{r}.072 \\
-.093 \\
.691 \\
.439 \\
-1.023 \\
.329 \\
-.152 \\
-.383 \\
-.248 \\
-1.485 \\
.574 \\
.143 \\
.101 \\
.137 \\
.884 \\
.932 \\
.618 \\
-8.946\end{array}$ & $\begin{array}{l}.724 \\
.415 \\
.593 \\
.850 \\
.532 \\
.730 \\
.004 \\
.310 \\
.468 \\
.004 \\
.439 \\
.095 \\
.076 \\
.016 \\
.000\end{array}$ \\
\hline
\end{tabular}

Source: Kinkel and Jäger (2017). 
The results show that supplier companies show a significant lower backshoring propensity than manufacturers of end products (original equipment manufacturers (OEMs)). This can be explained by close ties with customer companies at the foreign location, which often have to be supplied flexibly from a short distance, so that proximity to the customer is advantageous. In addition, the backshoring propensity increases with the export rate of the companies. For German companies that rely on an export model, the quality and flexibility of their production are decisive factors, which are also the most important motives for backshoring activities. In addition, the label 'Made in Germany' is often helpful for these companies in order to successfully sell their premium products abroad.

The results also display a significant positive correlation between the use of digitization technologies in manufacturing and the backshoring propensity of German manufacturing companies.

Advanced users (level 3), which introduced at least one technology from each of the three technology fields before 2013, have significantly more often shifted foreign production activities back to the German location than nonusers (level 0) of digitization technologies. According to the estimation model, advanced users of digitization technologies display on average a ten times higher backshoring propensity (approx. 5\%) than non-users of digitalization technologies (approx. 0.5\%). Also, beginners (level 1) and active users (level 2) are showing a higher backshoring propensity than non-users (level 0), albeit at a lower $10 \%$ level of significance.

Two arguments can be used to explain this correlation:

- First, the use of digitization technologies can lead to increased automation and productivity at the German production site, so that the labour cost ratio becomes lower, labour arbitrage in low-wage countries is less appealing and economies of scale at the remaining factory sites in developed countries become more important.

- Second, the use of digitization technologies can be used to increase the flexibility and ability for customized production in small batches with very low marginal cost, which allows the efficient and timely serving of individual customer requirements, and offers incentives to companies to bring back or hold production close to their European customers (leading to local value chains).

According to both arguments, the intensive use of digitalization technologies can significantly contribute to more attractive production conditions with increased added value at the German location.

\subsection{Conclusions}

Overall, the pressure for greater flexibility and responsiveness is likely to grow in the future, thus suggesting increasing consideration of backshoring options. Our 
results suggest that companies are continuing to internationalize their activities, but with greater sensitivity to critical factors than in the past. The advantages of cost-based offshoring activities to low-wage countries seem to diminish more and more as time passes, while market-related expansion investments in emerging markets, in order to get closer to the local customers and serve their needs in time, might gain further significance.

However, it is not easy to restore product and process competences outsourced some years ago and restore their 'industrial commons' (Pisano and Shih, 2009). In many cases it might be easier to build up capabilities for the next generation of products or technology, e.g. in the new and vibrant area of I4.0 technologies, as relearning of once-outsourced competences can be a difficult process and only results in catching up rather than becoming a market leader (Kinkel, 2014).

In light of the new potential of I4.0 and smart digitized manufacturing technologies, companies are increasing their focus on utilizing the strengths and potentials of their home base in high-wage countries in Europe. Therefore, we might envisage the beginning of a new strategic imperative of relocalized manufacturing (Brennan et al., 2015; Kinkel, 2014) in important markets, with a strong focus on regional concentration and specialization of the necessary engineering and manufacturing competences. Complete solution providing capabilities will be installed in all relevant markets, bidding farewell to further slicing value chains over locations with least-cost advantages, which has led to very complex, multi-stage global supply chains that often comprise many different players and locations. Such global chains are also vulnerable to damage in one of their links, endangering the reliability and responsiveness of the whole chain, which is a crucial condition for the success of companies in today's global economy.

Other factors supporting localized manufacturing (Brennan et al., 2015; Foresight, 2013) are as follows:

- $\quad$ Providing customized products and services, making it necessary to develop and produce customized solutions in smart and agile (responsive) modes close to local clients (Forfas, 2013; Foresight, 2013; McKinsey Global Institute, 2012).

- Rising labour costs in emerging countries as a result of their economic catching-up processes, rendering their comparative cost advantages more and more marginal compared to developed countries with a highly skilled workforce and lower wage volatility (Forfas, 2013; Foresight, 2013).

- Reduced weight of labour costs in total production costs, due to continuing automation and efficiency improvements in many manufacturing firms. For example, currently in the German manufacture industry, direct labour costs account for only around $10 \%$ or less of production output value. These progresses are paced by innovations in information and communication technologies and manufacturing technologies towards smart and digital factories, and I4.0 technologies play a vital role here. 


\section{References}

Abrahamson, E. and Rosenkopf, L. (1993) Institutional and competitive bandwagons: using mathematical modeling as a tool to explore innovation diffusion. Academy of Management Review, 18: 487-517.

Arlbjørn,J. and Mikkelsen, O. (2014) Backshoring manufacturing: notes on an important but under-researched theme. Journal of Purchasing \& Supply Management, 20(1): 60-62.

Bals, L., Jensen, P. D. Ø., Larsen, M. M. and Pedersen, T. (2013) Exploring layers of complexity in offshoring research and practice. In T. Pedersen, L. Bals, P. D. Ørberg Jensen and M. Møller Larsen (eds), The Offshoring Challenge: Strategic Design and Innovation for Tomorrow's Organization. London: Springer, pp. 1-18.

Barney, J. (1991) Firm resources and sustained competitive advantage. Journal of Management, 17(1): 99-120.

Barthélemy, J. (2001) The hidden costs of IT outsourcing. Sloan Management Review, 42(3): 60-69.

Bauernhansl,T. (2014) Die vierte industrielle revolution - der weg in ein wertschaffendes produktionsparadigma. In T. Bauernhansl, M. ten Hompel and B. Vogel-Heuser (eds), Industrie 4.0 in Produktion, Automatisierung und Logistik. Wiesbaden: Springer, pp. 5-35.

BCG (2011) Made in America, again. Why manufacturing will return to the U.S. Boston Consulting Group. Available at: www.bcg.com/documents/file84471.pdf.

Brennan, L., Ferdows, K., Godsell, J., Golini, R., Keegan, R., Kinkel, S., Srai, J. S. and Taylor M. (2015) Manufacturing in the world: where next? International Journal of Operations \& Production Management, 35(9): 1253-1274.

Broedner, P., Kinkel, S. and Lay, G. (2009) Productivity effects of outsourcing: new evidence on the strategic importance of vertical integration decisions. International Journal of Operations \& Production Management, 29(2): 127-150.

Brynjolfsson, E., and McAfee, A. (2014) The Second Machine Age: Work, Progress, and Prosperity in a Time of Brilliant Technologies. New York: Norton Publishers.

Buckley, P. J. and Casson, M. (1976) The Future of Multinational Enterprise. London: Macmillan.

Cabral, S., Quelin, B. and Maia, W. (2013) Outsourcing failure and reintegration: the influence of contractual and external factors. Long Range Planning, 47(6): 1-14.

Canham, S. and Hamilton, R. T. (2013) SME internationalisation: offshoring, 'backshoring', or staying at home in New Zealand. Strategic Outsourcing: An International Journal, 6(3): 277-291.

Casson, M. (2013) Economic analysis of international supply chains: an internalization perspective. Journal of Supply Chain Management, 49(2): 8-13.

Choi, T. Y. and Hong, Y. (2002) Unveiling the structure of supply networks: case studies in Honda, Acura, and DaimlerChrysler. Journal of Operations Management, 20(5): 469-493.

De Backer, K., Menon, C., Desnoyers-James, I. and Moussiegt,L. (2016) Reshoring: myth or reality? OECD Science, Technology and Industry Policy Papers No. 27.

Di Mauro, C., Fratocchi, L., Orzes, G. and Sartor, M. (2018) Offshoring and backshoring: a multiple case study analysis. Journal of Purchasing and Supply Management, 24(2): 108-134. 
Dicken, P. (2014) Global Shift: Mapping the Changing Contours of the World Economy. London: Sage Publications.

Dunning, J. H. (1980) Towards an eclectic theory of international production: some empirical tests. Journal of International Business Studies, 11(1): 9-31.

Dunning, J. H. (1988) The eclectic paradigm of international production: a restatement and some possible extensions. Journal of International Business Studies, 19(1): 1-31.

Ellram, L. M., Tate, W. L. and Petersen, K. J. (2013) Offshoring and reshoring: an update on the manufacturing location decision. Journal of Supply Chain Management, 49(2): 14-22.

Foerstl, K., Kirchoff, J. F. and Bals, L. (2016) Reshoring and insourcing: drivers and future research directions. International Journal of Physical Distribution and Logistics Management, 46(5): 492-515.

Ford, M. (2015) Rise of the Robots: Technology and the Threat of Mass Unemployment. New York: Basic Books.

Foresight (2013) The Future of Manufacturing: A new era of opportunity and challenge for the UK, Summary Report, Government Office for Science, London.

Forfas (2013) Making it in Ireland: Manufacturing 2020, Dublin.

Fratocchi, L., Ancarani, A. Barbieri, P., Di Mauro, C., Nassimbeni, G., Sartor, M.,Vignoli, M. and Zanoni, A. (2016) Motivations of manufacturing reshoring: an interpretative framework. International Journal of Physical Distribution \& Logistics Management, 46(2): 98-127.

Fratocchi, L., Di Mauro, C., Barbieri, P., Nassimbeni, G. and Zanoni, A. (2014) When manufacturing moves back: concepts and questions. Journal of Purchasing and Supply Management, 20(1): 54-59.

Fredriksson, A. and Jonsson, P. (2009) Assessing consequences of low-cost sourcing in China. International Journal of Physical Distribution \& Logistics Management, 39(3): 227-249.

Grant, R. M. (1991) The resource-based theory of competitive advantage: implications for strategy formulation, California Management Review, 33: 114-135.

Gray, J.V., Skowronski, K., Esenduran, G. and Rungtusanatham, M. (2013) The reshoring phenomenon: what supply chain academics ought to know and should do. Journal of Supply Chain Management, 49(2): 27-33.

Handfield, R. B. (1994) US global sourcing: patterns of development. International Journal of Operations \& Production Management, 14(6): 40-51.

Handley, S. M. and Benton Jr., W. C. (2013) The influence of task- and location-specific complexity on the control and coordination costs in global outsourcing relationships. Journal of Operations Management, 31(3): 109-128.

Holweg, M., Reichhart, A. and Hong, E. (2011) On risk and cost in global sourcing. International Journal of Production Economics, 131: 333-341.

Kagermann, H.,Wahlster,W. and Helbig, J. (eds) (2013) Recommendations for Implementing the Strategic Initiative INDUSTRIE 4.0: Securing the Future of German Manufacturing Industry. Final report of the Industrie 4.0 Working Group. acatech - Deutsche Akademie der Technikwissenschaften e.V., Berlin.

Kinkel, S. (2012) Trends in production relocation and back-shoring activities: changing patterns in the course of the global economic crisis. International Journal of Operations \& Production Management, 32(6): 696-720. 


\section{Steffen Kinkel}

Kinkel, S. (2014) Future and impact of backshoring: some conclusions from 15 years of research on German practices. Journal of Purchasing \& Supply Management, 20(1): 63-65.

Kinkel, S. and Jäger, A. (2017) Auslandsverlagerungen, Rückverlagerungen und Digitalisierungsverhalten in der deutschen Industrie. Trends und Auswirkungen für den Produktionsstandort Deutschland. Hochschule Karlsruhe - Technik und Wirtschaft.

Kinkel, S. and Maloca, S. (2009) Drivers and antecedents of manufacturing offshoring and backshoring: a German perspective. Journal of Purchasing and Supply Management, 15(3): 154-165.

Kinkel, S., Rieder, B., Horvath, A. and Jäger, A. (2016) Productivity and flexibility advantages of in-house manufacturing and local sourcing - The limits of global value chains? Proceedings of the 42nd Annual Conference of the European International Business Academy (EIBA).

Lasi H., Fettke, P., Kemper H. G., Feld T. and Hoffmann, M. (2014) Industry 4.0. Business and Information Systems Engineering, 6(4): 239-242.

Lewin, A. Y., Massini, S. and Peeters, C. (2009) Why are companies offshoring innovation? The emerging global race for talent. Journal of International Business Studies, 40(6): 901-925.

Lichtblau, K., Stich, V., Bertenrath, R., Blum, M., Bleider, M., Millack, A., Schmitt K., Schmitz E. and Schröter, M. (2015) Industrie 4.0-Readiness.Aachen:IMPULS-Stiftung.

McIvor, R. (2009) How the transaction cost and resource-based theories of the firm inform outsourcing evaluation. Journal of Operations Management, 27(1): 45-63.

McKinsey Global Institute (2012) Manufacturing the Future. The Next Era of Global Growth and Innovation. Seoul: McKinsey Global Institute.

Nassimbeni, G. (2006) International sourcing: empirical evidence from a sample of Italian firms. International Journal of Production Economics, 103(2): 694-706.

OECD (2016) OECD Science, Technology and Industry Outlook 2016. Paris: Organisation for Economic Co-operation and Development.

OECD (2017) Enabling the Next Production Revolution: The Future of Manufacturing and Services. Paris: Organisation for Economic Co-operation and Development.

Pisano, G. P. (1990) The R\&D boundaries of the firm: an empirical analysis. Administrative Science Quarterly, 35(1): 153-176.

Pisano, G. P. and Shih, W. C. (2009) Restoring American competitiveness. Harvard Business Review, 87(7/8): 2-14.

Pisano, G.P. and Shih,W.C. (2012) Producing Prosperity: Why America Needs a Manufacturing Renaissance. Boston, MA: Harvard Business Review Press.

Prahalad, C. K. and Hamel, G. (1990) The core competence of the corporation. Harvard Business Review, May/June: 79-91.

PricewaterhouseCoopers (2014) Reshoring: a new direction for the UK economy? UK Economic Outlook, March, pp. 25-33.

Ritter, R. and Sternfels, R. (2004) When offshore manufacturing doesn't make sense. McKinsey Quarterly, 4: 124-127.

Rugman, A. M. (2010) Reconciling internalization theory and the eclectic paradigm. Multinational Business Review, 18(2): 1-12.

Spath, D., Ganschar, O., Gerlach, S., Hämmerle, M., Krause, T. and Schlund, S. (2013) Produktionsarbeit der Zukunft - Industrie 4.0. Stuttgart: Fraunhofer Verlag. Available 
at: www.produktionsarbeit.de/content/dam/produktionsarbeit/de/documents/ Fraunhofer-IAO-Studie_Produktionsarbeit_der_Zukunft-Industrie_4_0.pdf.

Stentoft, J., Olhager, J., Heikkilä, J. and Thoms, L. (2016) Manufacturing backshoring: a systematic literature review. Operations Management Research, 9(3): 53-61.

Tate, W. L. (2014) Offshoring and reshoring: U.S. insights and research challenges. Journal of Purchasing and Supply Management, 20(1): 66-68.

Tate, W. L., Dooley, K. J. and Ellram, L. M. (2011) Transaction cost and institutional drivers of supplier adoption of environmental practices. Journal of Business Logistics, 32(1): 6-16.

Tate, W. L., Ellram, L., Bals, L. and Hartmann, E. (2009) Offshore outsourcing of services: an evolutionary perspective. International Journal of Production Economics, 120(2): 512-524.

Teece, D. J., Pisano, G. and Shuen, A. (1997) Dynamic capabilities and strategic management. Strategic Management Journal, 18(7): 509-533.

Teece, D. J., Pisano, G. and Shuen, A. (2002) Dynamic capabilities and strategic management. In G. Dosi, R. R. Nelson and S. G. Winter (eds), The Nature and Dynamics of Organizational Capabilities. New York: Oxford University Press, pp. 334-362.

Timmer, M. P., Los, B., Stehrer, R. and De Vries, G. J. (2016) An anatomy of the global trade slowdown based on the WIOD 2016 release. GGDC Research Memorandum 162, Groningen.

UNCTAD (2017) World Investment Report 2017: Investment and the Digital Economy. New York: United Nations.

Wernerfelt, B. (1984) A resource-based view of the firm. Strategic Management Journal, 5(2): 171-180.

Wiesmann, B., Snoei, J. R., Hilletofth, P. and Eriksson, D. (2017) Drivers and barriers to reshoring: a literature review on offshoring in reverse. European Business Review, 29(1): 15-42.

Williamson, O. E. (1985) The Economic Institutions of Capitalism. New York: Free Press.

World Trade Organization (WTO) (2011) Made in the World Initiative (MiWi). Available at: www.wto.org/english/res_e/statis_e/miwi_e/miwi_e.htm. 